общение с представителями другой культуры, понимание особенностей других сообществ и существующих мировых проблем [7]. На наш взгляд, особенности гражданственности у студентов Орехово-Зуева можно объяснить недостаточностью мультикультурного образования, а также условиями проживания в малом городе.

Bblвodbl

1. Уровень выраженности разных аспектов гражданственности зависит от регионально-образовательной среды: наиболее высокими являются показатели отношения к нормам гражданского общества, активности гражданской позиции и гражданской идентичности у студентов мегаполиса, наименее выражены у студентов областного города.

2. У студентов мегаполиса и областного города гражданственность является целостной характеристикой (все её стороны достоверно связаны между собой), а у студентов малого города гражданская идентичность не связана с отношением к нормам гражданского общества и активностью гражданской позиции.

$$
* * *
$$

1. Акимова М.К., Горбачева Е.И. Социальный капитал личности: нормативный подход к изучению и диагностике // Вопросы психологии. 2014. № 1. С. 58-67.

2. Акимова М.К., Горбачева Е.И., Рожкова А.В., Сысоева Т.А., Ярошевская С.В. Связь гражданской идентичности с социокультурным ресурсом среды и умственным развитием // Вопросы психологии. 2016. № 6. С. 76-85.

3. Акимова М.К., Персиянцева С.В. Влияние нормативности и конкретно-ситуативных факторов на просоциальное поведение молодёжи разных региональных выборок // Мир педагогики и психологии. 2019. №. 9 (38). С. 118-127.

4. Акимова М.К., Сысоева Т.А. Влияние региональных различий на специфику ценностного отношения к миру // Теоретическая и экспериментальная психология. 2014. Том 7. № 3. С. 6-16.

5. Асмолов А.Г. Как будем жить дальше? Социальные эффекты образовательной политики // Лидеры образования. 2007. № 6. С. 4-10.

6. Бергер П.Л. Культурная динамика глобализации. В кн.: Многоликая глобализация. Культурное разнообразие в современном мире / Под ред. П. Бергера, С. Хантингтона. М.: Аспект Пресс, 2004. C. 8-23.

7. Кожанов И.В. Зарубежный опыт формирования гражданской идентичности личности // Педагогическое образование в России. 2014. № 9. С. 229-233.

8. Российская идентичность в Москве и регионах / Под ред. Л.М. Дробижевой. М.: Институт социологии РАН, МАКС Пресс, 2009.

9. Гражданские, этнические и религиозные идентичности в современной России / Под ред. В.С. Магун, Л.М. Дробижевой, И.М. Кузнецова. М.: Институт социологии РАН, 2006.

10. Bennett C.I. Comprehensive multicultural education: Theory and practice. Boston: Allyn\&Bacon, 1990.

\title{
Ананьина О.B. \\ Взаимосвязь самоотношения с социометрическим статусом у старших школьников
}

Новокузнецкий институт (филиал) ФГБОУ ВО «Кемеровский государственный университет»

(Россия, Новокузнеик)

doi: 10.18411/lj-05-2021-295

\section{Аннотация}

В данной статье рассматривается вопрос о взаимосвязи самоотношения с социометрическим статусом у старших школьников. Рассмотрены разные подходы к понятиям: «самоотношение», «социометрический статус».

Ключевые слова: самоотношение, социометрический статус, старшие школьники, школьники. 


\section{Abstract}

This article examines the question of the relationship between self-attitude and sociometric status in older students. Different approaches to concepts are considered: «Selfattitude», «sociometric status».

Keywords: self-attitude, sociometric status, senior pupils, schoolchildren.

Самоотношение затрагивает практически все аспекты человеческого поведения и играет центральную роль в создании межличностных отношений, в том, как формировать и разрешать кризисные ситуации, определять и достигать целей, что дает нам основание рассматривать его в качестве основной предпосылки для саморазвития старшеклассников. В зарубежной и отечественной психологии самоотношение обычно рассматривается как эмоциональная составляющая самосознания, которая основана на самопознании, но с другой стороны, создает базовые предпосылки для саморегуляции, саморазвития и самооценки[7]. Основную роль самоотношении в нормальном функционировании личности играют такие зарубежные и отечественные психологи, как Ананьев Б. Г., Бернс Р., Божович И. И., Выготский Л. С., Джеймс У., Леонтьев А. Н., Лисина М. И., Липкина А. И., Пантилеев С. Р., Роджерс К. и др.

Самоотношение, как и многие понятия, имеет несколько значений. Так грузинский психолог Нодар Ильич Сарджвеладзе ввёл термин «самоотношение», который был определён как «отношение субъекта потребности к ситуации её удовлетворения, которое направлено на самого себя» [5].

С. Р. Пантилеев, опираясь на научные исследования В. В. Столина, определял самоотношение как «динамическую иерархическую систему, в которой та или иная особенная модальность эмоционального отношения качестве ядерной структуры системы, занимая ведущее место в иерархии других аспектов самоотношения, и фактически определяя содержание и выраженность обобщенного устойчивого самоотношения» [5].

Феномен самоотношения является объектом психологического анализа в работах отечественных и зарубежных ученых (Р. Бёрнс, У. Джеймс, К. Роджерс, С. Р. Пантилеев, Е. Т. Соколова, В. В. Столин, И. И. Чеснокова, Н. И. Сарджвеладзе) [4].

Для описания данного феномена в зарубежной литературе используются понятия «глобальная самооценка», «самооценка», «самоуважение», «самопринятие», «самоуверенность», «самоценность», «эмоционально-ценностное отношение к себе», «отношение к себе» [6]. Роберт Бернс в структуру Я-концепции включает «составляющую, связанную с отношением к себе или отдельным своим качествам», которую обозначает как «самооценка» или «принятие себя».

В отечественной литературе устойчивы синонимы «эмоционально-ценностное отношение к себе» и «отношение личности к себе». Последнее впервые упоминается в русле отечественных философских, философско-педагогических, а в дальнейшем и психологических исследований. Отношение личности к себе включено в структуру самосознания и отождествляется с самооценкой (А. Г. Спиркин), с эмоциональным отношением (А. Н. Леонтьев), с эмоционально-ценностным отношением к себе (И. И. Чеснокова) [7].

В теории «отношений» (А. Ф. Лазурский, В. Н. Мясищев) самоотношение обозначается как мера осознания и качество эмоционально-ценностного отношения к себе. Исследуемое понятие выступает как родовая категория ко всем видам отношений: эмоциональным, моральным и этическим (В. Н. Мясищев) [3].

В строении самоотношения выделяются самооценка и самопринятие (К. Роджерс); само понятие включаемо в структуру самооценки (Р. Бернс) или приравнивается к самооценке (С. Куперсмит) [2]. 
Обобщая позиции зарубежных авторов о строении самоотношения, С. Р. Пантилеев выделяет пять основных подходов к пониманию глобальной самооценки (общего самоуважения) [1].

1. «Я» - как конгломерат частных самооценок, связанных с различными аспектами Я - концепции.

2. Самоотношение как интегральная самооценка частных аспектов, взвешенных по их субъективной значимости.

3. Самоотношение как иерархическая структура включает частные самооценки, интегрированные по сферам личностных проявлений и в комплексе составлявших обобщенное «Я», которое находится на верху иерархии.

4. Глобальная шкала самооценки, которая относительно автономна и одномерна, так как выявляет некоторое обобщенное самоотношение, одинаково приложимое ко всем сферам «Я».

5. Самоотношение как чувство в адрес «Я», включающее переживания различного содержания (самоуверенность, самопринятие, аутосимпатия, отраженное отношение и т.д.) [7].

Таким образом, в представленных подходах прослеживаются два основных компонента: самооценка и эмоционально-ценностное отношение к себе, или так называемое чувство в адрес «Я», основанное на переживаниях различного содержания: самоуверенности, самопринятия, аутосимпатии, отраженного самоотношения и т.д. [2].

В отечественной литературе также исследуемое понятие связывается с самооценкой. Так, И. С. Кон обозначает положительное или отрицательное отношение к себе как производное от совокупности отдельных самооценок[7].

Социометрическая техника применяется для диагностики межличностных и межгрупповых отношений в целях их изменения, улучшения и совершенствования. С помощью социометрии можно узнать типологию социального поведения людей в условиях групповой деятельности, судить о социально-психологической совместимости членов конкретных групп[5].

Социометрия широко используется в социологии. В последние годы этот метод рекомендован к использованию в социальной психологии для изучения внутригрупповых отношений[2].

Вместе с официальной или формальной структурой общения, отражающей рациональную, нормативную, обязательную сторону человеческих взаимоотношений, в любой социальной группе всегда имеется психологическая структура неофициального или неформального порядка, формирующаяся как система межличностных отношений, симпатий и антипатий. Особенности такой структуры во многом зависят от ценностных ориентаций участников, их восприятия и понимания друг друга, взаимооценок и самооценок. Как правило, неформальных структур в группе возникает несколько, например, структуры взаимоподдержки, взаимовлияния, популярности, престижа, лидерства и др. Неформальная структура зависит от формальной структуры группы в той степени, в которой индивиды подчиняют свое поведение целям и задачам совместной деятельности, правилам ролевого взаимодействия. $\mathrm{C}$ помощью социометрии можно оценить это влияние. Социометрические методы позволяют выразить внутригрупповые отношения в виде числовых величин и графиков, и, таким образом, получить ценную информацию о состоянии группы[1].

Для социометрического исследования важно, чтобы любая структура неформального характера в тех или иных отношениях проецировалась на формальную структуру, т. е. на систему деловых, официальных отношений, и тем самым, влияла на сплоченность коллектива, его продуктивность. Эти положения проверены экспериментом и практикой[2]. 
Наиболее общей задачей социометрии является изучение неофициального структурного аспекта социальной группы и царящей в ней психологической атмосферы[4].

Было проведено исследование с помощью следующих методик:

1. Методика исследования самоотношения (МИС) (автор С. Р. Пантелеев);

2. Диагностика межличностных отношений (автор Т. Лири);

На основании которых были получены следующие результаты:

1. $\quad$ В исследуемой группе для большинства респондентов характерны шкалы «Самоуверенность» и шкала «Самопринятие», а именно по 26\% на каждую шкалу. Предположительно, показатели, полученные в ходе анализа данных психодиагностического тестирования, свидетельствует о том, что данная часть исследуемой группы имеет уважение к себе и относится к себе как к уверенному, самостоятельному и надежному человеку. Так же данная часть группы имеет согласие со своими внутренними побуждениями. У $20 \%$ респондентов преобладают высокие показатели по шкале «Самоценность» - это свидетельствует о том, что данная часть испытуемых предает ощущение ценности собственной личности и предполагаемую ценность собственного «Я» для других. Шкала «Самопривязанность» преобладает у $10 \%$ респондентов - это свидетельствует о желании изменяться по отношению к наличному состоянию. По 9\% набрали шкалы «Отраженное самоотношение» и «Саморуководство» - это означает, что характеризует представление субъекта о способности вызвать у других людей уважение, симпатию, а также отражает представление личности об основном источнике собственной активности, результатов и достижений.

2. В исследуемой группе преобладает дружелюбный тип отношений и составляет $66 \%$. 22\% составляет альтруистический тип отношение и по $4 \%$ распределилось на эгоистичный, подчиняемый и авторитарный типы отношений. Предположительно, полученные в ходе анализа данных психодиагностического тестирования, свидетельствует о том, что в данной группе преобладает дружелюбный тип отношений.

В ходе всего исследования был выбран такой метод как математический анализ по X. Пирсону. По результатам корреляционного анализа данных «Методика исследования самоотношения» С. Р. Пантелеева и «Диагностики межличностных отношений» Т. Лири можно сделать вывод о том, что есть значимая взаимосвязь между самоотношением и социометрическим статусом у старших школьников. А именно у респондентов, чья шкала самоотношения больше направлена на уверенность в себе, принятия себе и так далее, то те испытуемые имеют дружелюбный тип отношений с окружающими.

1. PsyJournals.ru : портал психологических изданий: сайт. - Москва, 2016 - . - URL : https://psyjournals.ru/ (дата обращения 15.04.2021). - Текст : электронный

2. Дэвид, М. Социальная психология / под ред. Е. Маслова ; [пер. с английского 3. С. Замчук]. - 7е.издание - Санкт-Петербург : Питер, 2019. - 272 с. - ISBN 978-5-4237-0138-3. - URL: https://www.litmir.me/bd/?b=217858 (дата обращения: 15.04.2021). - Текст: электронный.

3. Кавун, Л. В. Психология личности. Теории зарубежных психологов : учебное пособие для вузов / Л. В. Кавун. - 2-е изд., испр. и доп. - Москва : Издательство Юрайт, 2020. - 109 с. — (Высшее образование). — ISBN 978-5-534-07439-0. — Текст : электронный // ЭБС Юрайт [сайт]. — URL: https://urait.ru/bcode/453222 (дата обращения: 12.04.2021).

4. КиберЛенинка : научная электронная библиотека : сайт. - Москва, 2012 - . - URL: https://cyberleninka.ru (дата обращения: 12.04.2021). - Текст : электронный

5. Клементьев, Д. С. Социология личности : учебник для вузов / Д. С. Клементьев, А. Г. Маслова. 2-е изд., испр. и доп. - Москва : Издательство Юрайт, 2020. - 103 с. — (Высшее образование). — ISBN 978-5-534-08335-4. — Текст : электронный // ЭБС Юрайт [сайт]. — URL: https://urait.ru/bcode/451554 (дата обращения: 15.04.2021). 
6. Коломинский Я. Л. Психология детского коллектива: Система личных взаимоотношений. Минск: Народная Асвета, 1984. - 239 с. - текст непосредственный.

7. Чернышев, А. С. Социальная психология личности и группы : учебное пособие для вузов / А. С. Чернышев, С. В. Сарычев. - Москва : Издательство Юрайт, 2020. — 201 с. — (Высшее образование). - ISBN 978-5-534-13692-0. — Текст : электронный // ЭБС Юрайт [сайт]. — URL: https://urait.ru/bcode/466420 (дата обращения: 15.04.2021).

\section{Волкова М.Г. \\ Механизм конформизма и подчинения авторитету}

ФГКВОУ ВО «Ярославское высшее военное училище противовоздушной обороны»» Минобороны России (Россия, Ярославль)

doi: $10.18411 / \mathrm{j}-05-2021-296$

\section{Аннотация}

В статье проанализированы причины и проявление конформизма личности в социальной группе. Указаны негативные последствия конформного поведения, а также положительные аспекты такого поведения для воинских коллективов.

Ключевые слова: конформизм, авторитет, подчинение, ответственность.

\section{Abstract}

The article analyzes the causes and manifestations of individual conformism in a social group. The negative consequences of conformal behavior, as well as the positive aspects of such behavior for military collectives, are indicated.

Keywords: conformism, authority, submission, responsibility.

На социальное поведение личности оказывают влияние следующие механизмы: присутствия других людей, группового меньшинства, группового большинства, группового воздействия на деятельность и когнитивные процессы личности. Каждый из этих механизмов оказывает влияние на эмоциональные, когнитивные, волевые психические процессы и психологические состояния личности.

Рассмотрим более подробно механизм группового большинства, который выражается в эффектах конформизма и подчинения авторитету.

Эффект конформизма - это понятие, которое отражает изменения в поведении индивида, который испытал какое-либо давление (реальное или воображаемое) со стороны группы.

Соломон Аш определял конформизм как «отказ индивида от дорогих и значимых для него взглядов ради того, чтобы оптимизировать процесс адаптации к группе» [3, с. 253]. Конформное поведение указывает меру подчинения человека групповому давлению, необходимости принятия им определенного эталона, стереотипа поведения, которые были приняты в такой группе. В качестве ответа на давление группы индивид может показать один из четырех типов поведения:

- наружный конформизм - это не что другое, как приспособленчество и, в некой степени, фальшь. Человек создает видимость, что подчиняется правилам, создаёт иллюзию «корректности», не демонстрируя при всем этом собственного настоящего отношения. Этот вид конформности предполагает публичное соглашение личности с мнением большинства, хотя сам человек внутреннее может быть с ним не согласен;

— внутренний конформизм - это явление другого порядка. Индивид изменяет своё мнение, суждение под воздействием наружных причин и выбирает иную позицию. При подобном положении проводят аналогию 